\title{
ResistanCE, CLASS STRUGGLE AND SOCIAL MOVEMENTS IN LATIN AMERICA: CONTEMPORARY DYNAMICS
}

\author{
Henry Veltmeyer \\ Saint Mary's University, Halifax, Nova Scotia, Canada
}

\begin{abstract}
The article aims to discuss the different interpretations of the dynamics of the class struggle in Latin America and to develop the argument that these dynamics of contemporary social movements constitute a new and broader dimension in the confrontation with the structural changes of capitalist system. The arguments that the article seeks to advance are the debate on social movements that were circumscribed to the context of the neoliberal agenda and to the post-consensus of Washington, and to develop the reconstruction of the circumstances of the new millennium that gave rise to the new forces of change and resistance to the new frontier of extractive capital. The article concludes that the new social movements in Latin America do not fundamentally disrupt the structure of economic and political power, nor the capitalist system.
\end{abstract}

KEYWORDS: Social movements in Latin America. Marxist theory on social movements. Class struggle. Post-Consensus of Washington. Development in the capitalist periphery.

INTRODUCTION

For Marxists it is a matter of principle that the development of the forces of production within the institutional framework of capitalism - 
capitalist development, in short - generates forces of social change that can be mobilised in one direction or the other in the form of a class struggle and social movements that embody and advance the forces of resistance. However, on the Latin American periphery of the world capitalist system, the emergence in the 1980s of what appeared to some scholars armed with a postmodern political imaginary as a new type of social movement - 'new social movements' that were not class-based but that were expressive of a heterogeneity of a new historic subject and agency of social change - led to what was described within academe as a'theoretical impasse' and the end of history understood as a history of class struggle (SCHUURMANN, 1993; VELTMEYER, 1997).

This theory of new social movements would soon give way to a discourse on the emergence and strengthening of what would later be viewed as a 'civil society' formed within the spaces vacated by a retreating state - a state that was obliged to withdraw from the development process under the rules of the neoliberal world order. ${ }^{1}$ At the same time the emergence of political regimes committed to the neoliberal agenda of 'structural reform' in macroeconomic policy led to the formation of new sociopolitical movements that were mounted so as to mobilise the resistance of rural landless workers, peasant farmers and - in some contexts - indigenous communities. These movements led to a strengthening of the popular resistance to both the incursions of capital in the form of foreign direct investment (FDI) and multinational corporations and to the policy agenda of the governments that conformed to the Washington consensus. Given that the labour movement had been seriously weakened if not effectively destroyed by the forces of capitalist development, and that these new peasant-based movements displaced the leading role played by organised labour in an earlier period of capitalist development and class struggle, the emergence of these movements appeared to support the notion that the class struggle could no longer credibly be viewed as the dominant agency of social change, the motor force of history.

But this view has been disputed by scholars who note that although these movements were apparently community-rather than class-based, i.e. formed on the basis of a shared relationship to production, a salient feature of the new social movements that have dominated and still dominate the political landscape in the 2 st century is precisely the relation of community members to production, as well as the class nature of their demands for change, i.e. their engagement with the class struggle. Even so, while rejecting or moving beyond a postmodernist conception of the new social movements 
these scholars (for example, ZIBECHI, 2012b) note that the resistance has not taken the form of a class struggle for state power.

The geoeconomic and geopolitics of capital in the new millennium led to new forms of resistance. Whereas hitherto the struggle had been primarily over land or wages, or in mobilizing the resistance against the neoliberal agenda, the resistance now assumed the form of a territorial struggle, a struggle of communities to reclaim their right of access to 'the commons $^{\prime 2}$ as well as a struggle against the destructive impacts of extractive capitalism--resistance to the destruction of their livelihoods and way of life, the degradation of the environment on which their way of life depends, and the denial of their territorial and human rights (PRADA ALCOREZA, 2013). In their analysis of these social movement dynamics Raúl Zibechi and Anthony Bebbington among others argue that the resistance under these conditions does not take the form of a class struggle. Rather, they argue that it takes the form of localised subterranean struggles and everyday resistance (BEBBINGTON, 2009; BEBBINGTON \&BURY, 2013; ZIBECHI, 2012b).

The purpose of this paper is to sort out these different interpretations of the dynamics of struggle, and to advance the argument that these contemporary social movement dynamics in fact constitute a form and a new dimension of the broader class struggle (under conditions of capitalist development in a new and changing context). This argument is advanced in the face of studies such as Del Estado ficticio al Estado real (Plurinacional) by Humberto Echalar Flores (2015), who argues that the new dynamic forces of resistance puts to bed the Marxist theory of the class struggle as the motor force of social change as well as the relevance of class analysis of these forces of resistance. As Echalar sees and tells it the emergence of indigenous peasants on the stage of Latin American history, in the form of social movements and state power in Bolivia and Ecuador - i.e. with the formation of a plurinational (or multiethnic) state - makes clear that neither the working class nor an alliance between workers and peasants, as imagined in the 1960s and 1970s, constitute what Georg Lukacs - in his interpretation of the thinking of the early Marx — theorised as the 'identical subject-object of history'. To paraphrase Lukacs, the indigenous communities at the base of the social movements that have emerged in the most recent phase and conditions of capitalist development in the region constitute the new identical-object of history.

We advance this argument as follows. First, we briefly reconstruct the social movement dynamics of the 1990s under conditions of the neoliberal agenda and the post-Washington consensus regarding the need to bring the state back into the development process. In this context we offer a rather different interpretation of Latin American social movements than that 
offered by postmodernists in their interpretation of the Zapatista movement (BURBACH, 1994; HOLLOWAY, 2002). We then reconstruct the circumstances in the new millennium that gave rise to new forces of change and resistance on what could be described as the new frontier of extractive capital. Our argument is that the political dynamics of the resistance movement in this context can best be understood as a new modality of the class struggle, i.e. the 'communities in struggle' ${ }^{3}$ - particularly those that are negatively impacted by the operations of extractive capital - in the agency of their social movements can be understood as a 'new proletariat' and a dominant (albeit nonhegemonic) force for change in a progressive direction against both neoliberalism and capitalism.

\section{THE RESISTANCE, CLASS STRUGGLE AND SOCIAL MOVEMENTS IN AN ERA OF STATE- LED DEVELOPMENT}

In the context of the system and world order established in the wake of the Second World War the idea of 'development' (and the project of international cooperation) was constructed initially as a means of ensuring that in the process of liberating themselves from the yoke of colonialism and imperialist exploitation the so-called 'economically backward' countries on the periphery of the system would take a capitalist path towards national development. But in the aftermath of the Cuban Revolution the development project of international cooperation was rejigged and redesigned so as ensure that the'rural poor' - the proletarian mass of rural landless workers created by the capitalist development of agriculture - would turn away from the armies of national liberation and the movements seeking revolutionary change, essentially to prevent another Cuba and to dampen any fires of revolutionary ferment in the land struggle. The project of integrated rural development created to this purpose was the counterpart to the social reforms instituted in the cities and urban centres so as to prevent an upheaval and the rebellion of the working class, whose demands for improved working conditions and wages were advanced in the form of a labour movement but channelled by the state in a reformist direction. By the end of the 1970s the class struggle for land to all intents and purposes was over and the revolutionary social movements that engaged this struggle were either brought to ground or defeated by a combination of two class war strategies in the class war launched by capital against labour. One of these involved the idea and project of development, a project of technical and financial assistance (integrated rural development) that offered the rural poor a nonconfrontational path towards social change. The other was repression, deployment of the state apparatus of armed force 
(the velvet glove of development deployed in the first instance, and the iron fist of armed force when needed). ${ }^{4}$

The 1980s produced an entirely different context for the capitalist development process and the social movement dynamics on the periphery of the system. First, the installation of a new world order designed to liberate the forces of economic freedom from the regulatory constraints of the development state offset not only the process of revolutionary change but the liberal social reform agenda, advancing the capitalist development process but arresting and even reversing the slow but steady gains made by the working class and the peasantry via the agency of social movements. Second, the labour movement, the negotiating and organisational capacity of which had been severely weakened by actions taken by the state in concert with capital, was effectively destroyed by the working of forces released in the capitalist development process.

The capitalist development of industry on the periphery was predicated on the exploitation of the mass of surplus rural labour generated by the advance of capital in the countryside as well as a policy of import substitution industrialization. To promote the former the development agencies of international cooperation encouraged the rural poor to abandon the countryside and seek an improvement in their social condition and their lives by taking one or both of the development pathways out of rural poverty, namely, labour and migration (WORLD BANK, 2008). The problem here was that the institutional mechanism of this development, the labour market, had collapsed under the weight of the forces released in the capitalist development process. The structural reforms mandated under the Washington consensus regarding the virtues of free market capitalism-an opening to the world market, privatisation of the means of production and economic enterprise, liberation of the flow of investment capital and international trade in goods and services, and deregulation of capital and product markets ${ }^{5}$ - had the unintended but inevitable consequence of destroying built-up forces of production in both agriculture and industry. The result: the virtual disappearance of an industrial proletariat based on the capital-labour relation, and the formation of an informal sector in which workers were forced to work 'on their account' rather than exchange their labour power against capital for a living wage. Needless to say, this development also further weakened the class power of organised labour and the capacity to mobilise the forces of resistance against the advance of capital in the class struggle.

\section{THE NEOLIBERAL PIVOT OF THE SOCIAL MOVEMENTS}

The 1990s once again saw a different, albeit not entirely new, context for the capitalist development process and for the resistance in the form of 
social movements. On the one hand the structural reforms implemented under the Washington consensus led to the rapid advance of capital and a massive inflow of investment capital - a six-fold increase in these inflows just from 1990 to 1997, and, according to an analysis made by SaxeFernandez\& Nuñez (2001), an even more dramatic outflow of capital in the form of profit and returns on investments. ${ }^{6}$ On the other hand, the neoliberal 'structural reform' agenda, implemented by governments across the region to the purpose of facilitating these capital inflows and outflows, generated powerful new forces of resistance mobilised by a new generation of social movements rooted in the peasantry, the indigenous communities and a vast semiproletariat of rural landless workers (PETRAS \& VELTMEYER, 2005, 2009). ${ }^{7}$

The 1990s have been described as the 'golden age of imperialism', the leading agencies and agents of the empire having paved the way for a massive invasion of both profit, market and resource-seeking capital and the unhindered operations of the bearers of this capital (PETRAS \& VELTMEYER, $2001,2004)$. However, the decade could also be described as the 'golden age of the resistance' in that the social movements mounted by landless rural workers, peasants and indigenous communities had effectively derailed the neoliberal agenda - to the point that by the end of the decade neoliberalism as an economic model was in decline and to all intents and purposes was dead.

The irruption of the Zapatistas, a social movement that has been described as the 'first postmodern movement in history' (BURBACH, 1994) but that was no more than the rebirth of an army of national liberation brought to ground in the early 1980s, on the political stage on January 1994 was seen by many as the harbinger of a new wave of antisystemic social movements. However, the EZLN was by no means the first, nor the most dynamic movement in response to the neoliberal policy agenda. There was, of course the Movimento dos Trabalhadores Rurais Sem Terra (MST), a powerful social movement of 'landless rural workers' (semi-proletarianized peasants) that over the course of the decade occupied and managed to resettle on the land some 370,000 families on some 7.5 million hectares of land, land that they reclaimed through means of what movement leaders describe as 'the broader class struggle'(STEDILE, 2008). ${ }^{8}$ But one of the first and most powerful anti-neoliberal social movements in the region was formed by a federation of some 24 indigenous nationalities (CONAIE). In 1990 CONAIE mobilised the resistance of the indigenous communities against the neoliberal agenda of the Ecuadorian government in the form of an uprising, an uprising similar in form to an uprising ten years on that not only halted the neoliberal agenda in its tracks but resulted in the conquest of state power, albeit for only a 
few hours (PETRAS \& VELTMEYER, 2005). And these three social movements (the EZLN, the MST and CONAIE) were by no means alone. Similar forces of resistance and social movements were formed in Bolivia, in the form of los cocaleros, an organisation of former miners and coca-producing peasants led by Evo Morales, and in Paraguay, with the agency of the Federación Nacional Campesina (PETRAS \& VELTMEYER, 2005, 2009).

These social movements, all of which are class-based in terms of their demands and none of which could be described as postmodern in the sense ascribed by the theorists of the new social movements - i.e. as heterogeneous bearers of a 'new way of doing politics' - dominated the political landscape in the Latin American countryside in the 1990s. However, this dominance - and the limits of what they were able to achieve-has to be contextualized with reference to other dimensions of an ongoing class struggle and other forces and modalities of social change. Truth be told, we can identify three different 'ways of doing politics' at the time - three fundamental modalities of social change. The traditional way of doing politics - to seek social change by taking state power - was to resort to the electoral mechanism of democratic politics, to contest the national and local elections. However, the social movements took and still take a different path towards social change, electing to confront and challenge the political power structure by mobilizing the forces of resistance against it - the socalled 'revolutionary road' towards state power vs. the 'parliamentary road' (PETRAS \& ZEITLIN, 1968).

The third modality of social change is associated with the development project of international cooperation. ${ }^{9}$ As in the 1960 s and 1970 s the architects and practitioners of this project were concerned to provide the 'rural poor' an alternative and less confrontational approach and pathway towards social change than that provided by the social movements. To this end, in the 1990s the World Bank, which, together with the Inter-American Development Bank (IDB), assumed leadership of this project, took action to encourage activists in the indigenous movement (CONAIE, etc.) to turn towards democratic politics and the electoral mechanism in regards to their politics and 'development' (small-scale community-based projects) to advance their demand for social change - for an improvement in their social condition. As a result, by mid-decade Antonio Vargas, who had been the leader of CONAIE at the time of the 1990 uprising, had been transformed into the CEO of one of the largest and well-funded NGOs in Latin America. ${ }^{10}$ At the same time, some CONAIE activists and leaders had formed a political party, Patchakutik, that would allow the indigenous communities to contest both local elections and the national election. In practice, however, the formation of a political 
instrument with which to contest elections in a system of liberal democratic politics served to divide the movement and disperse the forces of resistance that CONAIE had organised and mobilised in various earlier conjunctures.

Bolivia underwent a similar development with the formation of the Movimiento al Socialismo (MAS), which served the social movements constructed on the base of the indigenous communities as a political instrument for contesting elections. However, Ecuador provides a model case of how to divide and demobilise a social movement by diverting resources and energy away from a strategy of social mobilization towards a strategy of contesting elections and relying on a strategy of local development-to bring about social change in their lives at the local level without confronting and challenging state power by mobilizing the forces of resistance. As for CONAIE as a social movement it was subsequently divided in three different directions, and by the end of the decade it was but a shadow of what it once was (the most powerful social movement in Latin America, able to successfully challenge state power and the government's neoliberal policy agenda).

There can be little or no doubt that the strategy of ethnodevelopment, and the politics of local development with the agency of development NGOs that were enlisted by the donors and the agencies of international cooperation to assist them in their project, was designed and tailored to the purpose of demobilising the social movements - to turn towards a nonconfrontational development project approach towards social change. There is also no doubt that a large part of the Left at the time bought into the strategy pursued by the World Bank and other agencies of international cooperation - or were unwitting accomplices (see, for example, BEBBINGTON, HICKEY \& MITLIN (2008). The thinking was as follows. The internecine divisive and sectoral politics of the traditional Left led to a widespread rejection within the popular movement of the old ways of doing politics via the agency of political parties. This rejection was encapsulated in the cry in the midst of a revolutionary struggle by los piqueteros in the streets of Buenos Aires - $i$ Que se Vayan todos! — and the need (articulated clearly by Comandante Marcos) for a different more indigenous way of doing politics, including 'to lead by following.' In support of this quest for a new politics, parts of the Left turned away from both the social movements (support of their mobilizations) and democratic politics. This new social Left that had materialised in the form of NGO activism - mediating between donor and the communities in the belief that they were assisting the communities rather than the donors in realising their strategic goal and objectives (PETRAS \& VELTMEYER, 2001). Even in the 1990 s when CONAIE held a dominant position in social movement organizing 
the leadership bought into this ideology, staking out a centre-left position generally associated with the NGOs. And the same was true for Bolivia where Morales on achieving state power with the support of the social movements enlisted for his cabinet a significant number of individuals, many of them women even before his government adopted a policy of gender parity, not from the social movements but from the NGO sector.

These three modalities of social change - electoral politics, social mobilization, local development ${ }^{11}$ — do not always play out the same way. In Ecuador, for example, pursuit of a state-led development strategy with international cooperation and social/popular participation led to a weakening and the demobilization of what had been a powerful social movement with a notable capacity to mobilise the forces of resistance. The end result was a failure to achieve state power - to tread either the parliamentary or revolutionary road to state power. In Bolivia, however, the three modalities of social change were effectively combined in various conjunctures of a process that would lead to the ascension of Evo Morales to state power as leader of an indigenous social movement and as leader of what is described as a political movement but functions as a party - not to mobilise the resistance but to contest - in this case successfully - the elections (Webber, 2005, 2006). In effect, Morales achieved state power by using the electoral mechanism and the party apparatus, but he did so with the active support and on the social base of the social movements, both the indigenous movement and a part of the labour movement. This electoral strategy would never have worked were it not for the active mobilization of the indigenous communities and the working class brought about by the agency of what in effect was a revolutionary social movement. In fact, in stepping away from the heat of the class struggle at a crucial juncture of the revolutionary situation in pursuit of his electoral strategy Morales almost lost control of the movement and thus his election to the presidency.

\section{REGIME CHANGE AND CAPITALIST DEVELOPMENT IN THE NEW MILLENNIUM}

The new millennium once again provided conditions for launching a new phase of capitalist development and a corresponding change in both the relations production and the dynamics of the class struggle. At issue here was the emergence of a progressive cycle in Latin American politics - a pink and red tide of left-leaning'progressive regimes' committed to moving beyond neoliberalism (GRUGEL \& RIGGIROZZI, 2012; LEVITSKY \& ROBERTS, 2011; MACDONALD \& RUCKERT, 2009). Although there is a continuing debate on this question of regime change it would appear to be the result of a number 
of changing conditions. One was the widespread disenchantment with and rejection of neoliberalism, which can be attributed to the activism of the social movements formed in the 1990s in the resistance against the policies pursued by the neoliberal regimes in the 1990s in a second cycle of 'structural reforms' (PETRAS \& VELTMEYER, 2006). Another was the formation of a new consensus on the need to bring the state back into the development process and bring about a more inclusive form of development (INFANTE \& SUNKEL, 2009). A third 'development' related to changes in the world capitalist system and global economy: the ascension of China as an economic power and an associated spurt in the demand for energy and natural resources to fuel the expanding economies and 'emerging markets' of China and the BRICS.

One of several outcomes of these changing conditions was the emergence and formation of what some analysts conceptualised as a postneoliberal state, with reference to the 'inclusionary state activism' of the 'progressive' (centre-left) political regimes formed in this conjuncture of the capitalist development process (BARRETT, CHAVEZ \& RODRÍGUEZ, 2008; FINE \& JOMO, 2006; PETRAS \& VELTMEYER (2005). A second outcome was a heated and as yet unsettled debate regarding the pros and cons of several economic models: the neoliberal model promoted by the US and the guardians of the new world order, and used by the government in Mexico, Colombia, Peru (and undoubtedly by Argentina after Macri's ascension to state power); the neodevelopmentalist model used until 2016 as a guide to macroeoconomic development policy in Argentina, Brazil, Chile and Uruguay; the Vivir Bien or Bien Vivir model used to frame a strategy of national development and as a guide to policy by the current governments of Bolivia and Ecuador; and the model of $21^{\text {st }}$ century socialism constructed by Hugo Chávez and still pursued-albeit in conditions of a vicious class struggle-by the Maduro regime in the Bolivarian Republic of Venezuela.

Not only is the Maduro regime in crisis and beset by forces released in an ongoing class struggle but each of these development models and associated political projects in their own way are immersed in crisis (PETRAS \& VELTMEYER, 2017). One of the conditions of this crisis is the pursuit of so many governments in the region (mostly in South America, as it happens) of an extractivist strategy of natural resource development and the export of these resources in primary commodity form (GUDYNAS, 2009). All of the governments mentioned above, no matter the policy regime (neoliberal or post-neoliberal), have elected to incorporate extractivism - natural resource extraction and primary commodity exports - into their national development plan, fomenting a heated theoretical and political debate, but pushing each government into a crisis. 
The implementation by various governments of extractivist model of national development - extractivism or neoextractivism, as the case might be - have not only generated conditions of a profound political crisis (and the apparent end of a progressive cycle in Latin American politics) ${ }^{12}$ but also an extended policy and theoretical debate on the contradictions and pitfalls of extractivism - particularly as regards its negative socioenvironmental impacts but also what economists have described as a 'resource curse' (ACOSTA, 2009, 2011; AUTY, 1993), not to mention the Dutch disease and a propensity towards social exclusion, as well as the concentration of benefits of resource-led growth together with enormous social economic and environment costs, the brunt of which are borne by communities contiguous to the sites of extractive operations.

In the vortex of the debates and the political conflicts that surround extractivism some peasant and indigenous movements have not only engaged the resulting political conflicts and a class struggle over access to the commons, but they have joined the theoretical and political debate regarding projects of alternative development or alternatives to development (ABYA YALA, 2009).

Many of the organizations in these movements have coalesced and formed an alliance to the purpose of sharing experiences and ideas. In the case of Via Campesina, an international movement of 'peasants' (basically smalllandowning cooperative and family farmers committed to an anti-capitalist non-corporate model of agricultural development), as well as Via Campesina Brazil, a key player in Via Campesina, these ideas have crystallised into a vision and model of a sustainable form of agriculture based on the virtues of smallscale production for local markets and the principles of an agroecological revolution that has swept across academe - agroecology as part of a broader program of agrarian reform (ROBLES \& VELTMEYER, 2015; VIA CAMPESINA, 2012; VIA CAMPESINA-BRAZIL, 2008). ${ }^{13}$ These peasant movements, together with the continental alliance of indigenous communities and social movements (ALAI), are all but united in their opposition to the corporate agribusiness model and the capitalist global food regime (ABYA YALA, 2009).

\section{THE RESISTANCE, CLASS STRUGGLE AND SOCIAL MOVEMENTS ON THE EXPANDING} FRONTIER OF EXTRACTIVE CAPITAL

A class struggle over access to the commons (land and natural resources) and associated conflicts have been part of Latin America for a long time, a fundamental legacy of the capitalist development process, which at the beginning involves the resistance and the struggle of communities against 
conditions conceptualised by David Harvey (2003) in terms of a process of 'accumulation by dispossession' - the separation of the direct producers from the land and their means of production, and a resulting proletarianization' (conversion of a peasantry into a proletariat and a working class of some sort or the other). In these terms the capitalist development of the forces of production in the agricultural sector, and the corresponding process of productive and social transformation, is advanced in two ways. First, by exploiting the mass - and, according to Sir Arthur Lewis, the 'unlimited supply' - of surplus rural labour generated by the transition towards capitalism. And secondly, (according to Ruy Mauro Marini) ${ }^{14}$ by means of 'superexploitation' - remunerating or 'rewarding' labour (working class and the small-landholding direct producers on the periphery of the system) at below its cost of production. This is the fundamental form taken by capitalism, namely, the exploitation of labour. However, capitalism also takes another form: extractivism - the extraction of natural capital, the wealth of natural resources bound up in land - and the transfer of these resources from the periphery to the centre of the system. This is the dominant form taken by capitalism in Latin America prior to the $20^{\text {th }}$ century (GIRVAN, 2014).

Capitalism in the form of natural resource extractionis bound up with the beginnings of the world capitalist system in the fifteenth century. However, in recent decades - with the massive inflows of 'resource-seeking' capital in the form of FDI (what we might describe as the'new geoeconomics of capital') - there has been a pronounced shift towards extractivism as a development strategy (the second pillar of the new development model used by many governments, and, as an adjunct to this strategy, towards a '(re) primarization of exports (CYPHER, 2012).

This 'development' is reflected in the increased use of landgrabbing ('large-scale foreign investments in the acquisition of land'), commodification (via privatization of the means of production and access to natural resources such as water, concessions to explore and extract metals and minerals, violation of territorial rights and environmental degradation as mechanisms of 'accumulation by dispossession' - the accumulation of extractive capital - what some analysts have conceptualized as a new way of 'enclosing the commons' (SPRONK \& WEBBER, 2007).

Under these conditions both the resistance and the class struggle have necessarily assumed new forms, as have the social movements that can best be understood as an expression of the class struggle in the current conjuncture of capitalist development. 
There is a burgeoning literature that analyzes the emergence of socioenvironmental conflicts related to the extractive sector - to the negative impacts of extractivism on both the environment and rural livelihoods and thus the sustainability of an indigenous culture and an entire way of lifeway of life environment. This literature can be placed into four categories. First, there are those studies that explore the sociopolitical and cultural implications of such conflicts for development policies and processes (TETREAULT, 2014; COLLIER \& VENABLES, 2011).

A second set of studies stress the implications of these conflicts on state-building processes as part of shifting interrelations between social movements, corporations and states (BEBBBINGTON, 2009). And a third set of studies explores the negative socioenvironmental impacts of extractivism and the political responses of local communities directly affected by them, which is to demand respect for their territorial and human rights and the accountability of powerful state and corporate interests for undermining their sources of livelihood (POLISCHUK, 2016; SAGUIER, 2014; TETREAULT, 2014). As Martinez-Alier (2003) sees it, conflicts emerge when there are asymmetric expectations and understandings concerning the economic, ecological, social, and cultural value of different resource-sensitive projects. And a fourth small group of studies have begun to explore the regional and international dimensions of extractivism and related socioenvironmental conflicts (COLLIER \& VENABLES, 2011; TETREAULT, 2014; VELTMEYER \& PETRAS, 2014).

Another set of studies and approach, one used in the mainstream of development thinking and practice, focuses on how these conflicts can be managed (COLLIER \&VENABLES, 2011). From this conflict resolution or resource management perspective the problems associated with the political economy of natural resource extraction are not systemic or endemic but can be 'managed', while the negative impacts and associated social and environmental costs mitigated. Resource conflict management, it is argued, is a matter of 'corporate social responsibility' and 'good governance', which includes engagement of the communities, even 'civil society', in the process of securing a'social license' to operate (explore and extract) in addition to a governmentissued concession to explore for resources and a license to operate.

In addition and in contrast to these studies, a number of scholars have begun to explore the social class dynamics of these socioenvironmental movements that have sprung up on the latest frontier of capitalist development (VELTMEYER \& PETRAS, 2014). From this class struggle perspective, extractivism represents the emergence of a new form of rentier capitalism based on the pillage of natural resources rather than the more customary exploitation of labour. It can also be seen as a new form of 
imperialism, which, according to Girvan (2014:49-61), in the historical context of the Americas has always involved pillage.

From this perspective the socioenvironmental conflicts and resource wars that have surrounded the contemporary operations of extractive capital are viewed as a new form of 'primitive accumulation' as Marx had it (to separate the direct producers from their means of production, forcing their expulsion from the land and leading to their proletarianization). Essentially, it is argued that the operations of extractive capital represent a new form of enclosing the commons - denying the indigenous and farming communities close to the mines and extractive operations of capital access to the global commons of land, water and resources, and denying any respect for the territorial rights claimed by the indigenous communities.

The mechanism of 'enclosure' in this analysis is the concession granted by the state to the corporations to explore for and extract the sub-soil resources (oil and gas, minerals and metals) from land occupied or owned by these communities or their members. Therefore, the form taken by the resistance on the new frontier of extractive capital includes rejection of the economic model used by the governments to make public policy in the area of economic development; the demand that their territorial and human rights be respected; and, above all, protests against the negative impact of extractivism on both their livelihoods and the environment on which they depend.

The destruction of the livelihoods of the communities contiguous to and most directly affected by the operations of extractive capital stems not only from their negative socioenvironmental impacts, but from the contradictory practices and policies associated with resource-driven'economic development' discussed above. These practices reflect what has been defined as the logic of 'accumulation by dispossession' (HARVEY, 2003). This refers to a mode of wealth generation at the social cost of depriving people of their territorial and human rights and causing ecological destruction. Accumulation by dispossession has been characteristic of diverse and prevailing forms of capitalism where accumulation depends on expanding the boundaries of a global market via the privatization and commodification of nature, i.e. land, water, and natural resources such as sub-soil minerals, fauna and the forest. Some suggest that indigenous peoples are particularly vulnerable in this regard since they are directly dependent on nature, the rich biodiversity of rain forests, rivers and land, not only for their livelihood and material subsistence but for their social and cultural reproduction, which is to say, their very existence. 
Large-scale mining, particularly in the form of open-pit mining, with the use of cyanide and mercury in the mineral extraction process is responsible for the pollution of the region's precious water reserves. This could potentially lead to the decimation of fish in rivers, health problems for people exposed to contaminated water, loss of fertile land, and shortages of clean water for human and animal consumption. Needless to say, fishing and the husbandry activities of communities located near mining sites are put at risk or are compromised.

As already mentioned the communities of peasant farmers and indigenous peoples are particularly vulnerable. In the region of the Southern Andes — and the border between Chile and Argentina — large-scale mining activities have been responsible for the pollution of mountain glaciers and downstream water, such as in the case of Barrick Gold's Pascua Lama project. Mining is a particularly environment-sensitive industry that has led to conflict in connection to its negative social and ecological consequences. Throughout Latin America out of a total of ongoing 184 resource conflicts 154 of them are mining-related (Table 1). These conflicts have affected 222 communities (179 of them in South America) and involve 247 companies (SAGUIER, 2014: Table 7.1. N. 6).

Table 1 Socioenvironmental conflicts related to mining in Latin America, 2006-2010

\begin{tabular}{c|c|c|c|c}
\hline Countries (selected) & Conflicts & \multicolumn{2}{|c|}{ Projects } & Companies \\
\hline Argentina & 24 & 30 & 43 & 37 \\
\hline Bolivia & 5 & 6 & 7 & 21 \\
\hline Brazil & 21 & 21 & 37 & 34 \\
\hline Chile & 25 & 28 & 42 & 20 \\
\hline Colombia & 16 & 32 & 21 & 5 \\
\hline Ecuador & 4 & 5 & 4 & 4 \\
\hline Guatemala & 4 & 4 & 7 & 15 \\
\hline Mexico & 13 & 13 & 17 & 28 \\
\hline Peru & 26 & 26 & 42 & \\
\hline
\end{tabular}

Source: OCMAL (2011).

\section{THE CLASS STRUGGLE AND SOCIAL MOVEMENT DYNAMICS OF THE RESISTANCE}

A class analysis of these socioenvironmental conflicts and associated struggles and social movements is concerned with three sets of issues, each a matter of debate. The first has to do with the social base of these social movements, establishing the social relation of community members to the system of economic production. The second concerns the matter of 
understanding the relationship of the communities affected by the operations of extractive capital with both the state and with the companies involved, as well as the relationship of capital to the state. A third issue, which is not explored here, concerns the political dynamics of the broader class struggle.

In regard to the first issue, the prevailing view is to see community members as a proletariat, the latest victims of the capitalist development process in which the direct producers are separated from their means of production as a mechanism of capital accumulation - 'accumulation by dispossession', as Harvey (2003) has it. In the classical context analyzed by Marx the mechanism of accumulation - the generation of a proletariat, or a class for hire, and with it a reserve army of surplus labour — involved the enclosure of the commons needed by the communities of small-scale direct producers, or peasant farmers, to subsist. In the contemporary context analysts have established two mechanisms of dispossession: one is large-scale foreign investment in the acquisition of land, or 'landgrabbing' (BORRAS, FRANCO, GOMEZ, KAY \& SPOOR, 2012); the other is enclosure of the commons by means of a public policy of privatization and commodification, converting natural resources into means of production and productive resources or assets.

Extractivism in the current context has taken and is taking diverse forms, including 'landgrabbing ${ }^{\prime 15}$ and enclosures of the commons: large-scale foreign investments in the acquisition of land with the aim of securing access to natural resources for extraction and sale on the world market. Although it has not generated significant forces of resistance or any social movements, it has resulted in a relation and condition of conflict with the local communities who are pressured to abandon the land either by the local agents of the foreign or local investors, or by legislative or administrative fiat.

A second dimension of the class struggle on the expanding frontier of capitalism is the relation of the communities negatively impacted by the mining of minerals and metals, and by the commodification and extraction of water and other resources, to the companies in the extractive industry and to the state. The relation of the communities to these companies is one of economic exploitation and political conflict. However, their relation to the State, or the role of the state in this struggle, is a different matter and very much at issue. By a number of accounts (see, for example, the case studies in VELTMEYER \& PETRAS, 2014), because of a coincidence of economic interest (resource rents and additional fiscal resources for the government, super-profit for the companies) the state tends to side with the companies in their relation of conflict with the communities negatively affected by the operations of extractive capital. 
A revealing example of this is Peru under President Humala who came to power in June 2011 with a promise to support local communities against the mining companies (on a platform of 'water before gold'). However, when open and violent protests erupted between the Canadian mining company Minera Afrodita and the Awajun indigenous communities in town of Bagua, the Armed Forces under his watch turned against the protesters, resulting in 33 deaths, 200 wounded and 83 detentions. This event on June 29, 2013, was the last episode of a long process of protests led by the Awajun to oppose the concessions of exploration and exploitation rights to Afrodita in an area located in the Cordillera del Condor region where there has been a longstanding controversy between the government, indigenous communities, and the company (IWGIA, 2010).

The main 'actors' involved in this 'politics of resistance' against the incursions of capital in the exploitation of natural resources - and the Minera Afrodita-Awajun struggle is but one of many such struggles all across the region - are the predominantly indigenous communities that populate the areas ceded by the different governments (be they neoliberal or postneoliberal in form) to the foreign mining companies for the exploration and exploitation of natural resources in their territorial lands. But they also include an array of civil society groups and NGOs that have been drawn into the conflict between global capital and local communities. And the forces of resistance to extractive capitalism and resource imperialism also include new social movements formed to protest against the damage caused by resource extraction to the environment, as well as against its effects on the health and livelihoods of the local population and the miners themselves, who face lifethreatening working conditions and health concerns. In other words, many of these movements are mounted by those negatively affected by the impacts of resource extraction and mining operations (for example, Red Mexicana de Afectados por la Minería and the Confederación Nacional de Comunidades del Perú Afectadas por la Minería or CONACAMI).

The social classes and 'actors' who engage these forces of resistance frequently use tactics such as marches and demonstrations, road and access blockades, and other forms of direct collective action to impede mining operations. According to a forum of people, communities and groups affected by the operations of mining capital, the exploitation of the region's mineral resources in 2009 had reached levels never before experienced (FPIMCCBV, 2010). Of particular concern was the Amazon region, where abundant deposits of gold, bauxite, precious stones, manganese, uranium and other materials are coveted by the companies operating in the mining sector. 
Another concern was the perceived connection between the multinational corporations in the sector and a host of foundations and NGOs with an alleged humanitarian or religious concern for the environment and the livelihoods of indigenous peoples and communities. In this connection, Eddy Gómez Abreu, president of the Parlamento Amazónico Internacional, declared that they had "incontrovertible evidence of these multinationals and foundations, under the cover of supposed ecological, religious or humanitarian concerns, collaborat[ing] in the effort to extract...strategic minerals," as well as espionage and illegal medical experiments on the indigenous population (Sena-Fobomade, 2011). In effect, he alleged that the mining companies regularly used foundations and other NGOs as one of their tactics to secure the consent of the local population to their projects and operations, and to manipulate them. If this is true, these foundations and the NGOs continue to serve in the tradition (and sordid history) of the European missionaries in their missiontohelp the indigenous population to adjust to their new world.

\section{CONCLUSION}

In the pre-neoliberal era, the resistance and the popular movements in Latin America were primarily concerned with demands related to the land struggle and the labour struggle for improved wages and working conditions. But in the 1990s the popular movement, with the agency ofpeasant-based social organizations and indigenous communities, mobilized against the state in the form of the neoliberal policies of the governing regimes. By the end of the decade, some of these movements, led by semiproletarianized indigenous peasant farmers and rural landless workers (for example in Ecuador, Chiapas, Brazil and Bolivia) had achieved one major gain in the struggle, which was to place the existing neoliberal regimes on the defensive and provoke a legitimation crisis regarding the economic model used by most governments to make public policy.

By the turn into the twenty-first century this model (neoliberal globalisation)for all intents and purposes was dead, no longer able to serve its legitimating functionor as a template for public policy. The social movements, organised by what remained of the peasantry as well as the mass of rural landless workers and the indigenous communities, had played an important role in advancing the class struggle - in creating the conditions for regime change and a new progressive cycle in Latin American politics. Thus the road to state power by the political left in the first decade of the new century was paved by the activism of the social movements in their resistance against the neoliberal policy agenda.

However, the role played by the social movements in the next and current phase of the class struggle is not so clear. On the one hand, the 
collective organised protests against the destructive operations of extractive capital engaged and mobilised the forces of resistance not just against the policy agenda of the governing regimes, but to some extent turned them against the operative capitalist system. Thus the so-called politics of natural resource extraction has turned out to be not merely a matter of better resource management, a post-neoliberal regulatory regime, a more socially inclusive development strategy or a new form of governance - securing the participation of local communities and stakeholders in the strategic decisions of policy makers. The opposition to, and resistance against, the neoliberal policy agenda took form not only in the search for an alternative form of (capitalist) development but as a rejection of the underlying system: 'postdevelopment', one might argue (GUDYNAS, 2017).${ }^{16}$ On the other hand, the new social movements formed in recent decades on the frontier of extractive capital in the Latinamerican countryside have not been able to engage with the broader class struggle, consigning themselves to historical irrelevance in the ongoing process of social changeand transformative development.

The anti-extractivist protesters and the resistance of those negatively impacted by the destructive operations of extractive capital - as for example, in the Mexican context, the Asamblea Nacional de Afectados Ambientales (ANAA) - have garnered international activist (and academic) recognition as part of a global environmental justice movement (rather than as a class struggle). But, just like the officials and functionaries of the neoliberal regimes found up and down the Pacific Coast (excluding Ecuador) from Chile to Mexico, officials of the post-neoliberal regimes formed in the recent'progressive cycle of' of Latin American politics do not embrace these protestors and critics. Indeed, like Rafael Correa, President of a country that has gone so far as to embed the postdevelopment concept of Buen Vivir in the Constitution, in a coincidence of economic interest with Global Capital has branded the leaders of the socio-environmental (anti-extractive) movements as criminals and terrorists who are prepared to put the environment ahead of the country's poor and its development. Dismissing or criminalising these anti-extractivist social movement activists and their supporters in the international and NGO community-or, in the case of Álvaro García Linera, Bolivia's Vice-President, viewing them as stooges of US imperialism or outside interests - the agents and officials of the regimes formed in what remains of the 'progressive cycle' have denounced them as provocateurs or environmental terrorists (FIDH, 2015). ${ }^{17}$ Thus the politics of resistance against natural resource extraction, and the social movements formed in this resistance, resolves into a particular dimension of the broader class struggle - combatting the workings of capitalism and mobilizing the forces of resistance located in the indigenous communities of semi-proletarianized peasant farmers. 
This is one conclusion that can be drawn from our review of social movement dynamics in the current context — that these socioenvironmental movements are in the vanguard of the resistance. But another conclusion is that these movements do not fundamentally challenge the power structure, the ruling classor the underlying system. As argued by Raul Zibechi (2012b), and other theorists of the new social movements formed on the frontier of extractive capital, these movements are not anti-systemic; the social and political struggles that they convey tend to be episodic and localised, and are not revolutionary in any way. They are disconnected from the main arena of the class struggle, which revolves around the capital-labour relation and the politics of regime change. With the exception of Bolivia, where it could be argued that the indigenous social movements played a crucial role in Evo Morales' ascent to state power, the social movements in the current context of Latin American politics are not positioned, nor have the power, to challenge the guardians of the dominant capitalist system. For this we have to await the resurgence of the labour movement and a much-needed reconstruction of the political Left.

Artigo recebido em: 27/03/2017 Aprovado para publicação em: 19/05/2017

RESISTÊNCIA, LUTA DE CLASSES E MOVIMENTOS SOCIAIS NA AMÉRICA LATINA: DINÂMICAS CONTEMPORÂNEAS

Resumo: O artigo tem o objetivo de discutir as diferentes interpretações sobre as dinâmicas da luta de classes na América Latina e, ainda, desenvolver o argumento de que estas dinâmicas dos movimentos sociais contemporâneos constituem uma nova e mais ampla dimensão no enfretamento às mudanças estruturais do sistema capitalista. $\mathrm{O}$ artigo procura abordar os argumentos sobre o debate relativo aos movimentos sociais que estavam circunscritos ao contexto da agenda neoliberal e ao pós-consenso de Washington, bem como desenvolver a reconstrução das circunstâncias do novo milênio que deu origem às novas forças de mudanças e deu resistência à nova fronteira do capital extrativo. $\mathrm{O}$ artigo chega à conclusão de que os novos movimentos sociais na América Latina não desafiam fundamentalmente nem a estrutura do poder econômico e político nem o sistema subjacente.

Palavras-chave: Movimentos sociais na América Latina. Teoria Marxista sobre movimentos sociais. Luta de classes. Pós-Consenso de Washington. Desenvolvimento na periferia capitalista. 
RESISTENCIA, LUCHA DE CLASES Y MOVIMIENTOS SOCIALES EN AMÉRICA LATINA: DINÁMICAS CONTEMPORÁNEAS

RESUMEN: El artículo tiene el objetivo de discutir las diferentes interpretaciones sobre las dinámicas de la lucha de clases en América Latina y, además de eso, desarrollar el argumento de que las dinámicas de los movimientos sociales contemporáneos constituyen una nueva y más amplia dimensión en el enfrentamiento a los cambios estructurales del sistema capitalista. El artículo busca tratar los argumentos sobre el debate relacionado a los movimientos sociales que estaban circunscriptos al contexto de la agenda neoliberal y al post consenso de Washington, así como desarrollar la reconstrucción de las circunstancias del nuevo milenio que originó las nuevas fuerzas de cambios y resistencia a la nueva frontera del capital extractivo. El artículo concluye que los nuevos movimientos sociales en América Latina no desafían fundamentalmente ni a la estructura del poder económico y político ni al sistema subyacente.

Palabras clave: Movimientos sociales en América Latina. Teoría Marxista sobre movimientos sociales. Lucha de clases; Postconsenso de Washington. Desarrollo en la periferia capitalista.

\section{NOTES}

1 The concept of 'civil society' was formulated in the 1980s in the context of a movement to democratize the state and society relation. Here civil society, in the form of nongovernmental development organizations, was conceived of as an intermediary, a partner in the project of international cooperation-'social participation', in development discourse (vs. 'political participation' in democratic discourse). In the field of international development, however, it did not enter into the discourse until the 1990s in the context of a United Nations project designed to incorporate the'private sector' of profit-seeking corporations into the development process (MITLIN, 1998). In the 1980s 'civil society' as a separate sphere, encompassing all manner of nongovernmental or social organizations between the family and the state, was conceptualized as a'third sector' (neither public nor private).

2 The concept of 'the commons' has various points of reference, including the notion of a territorially-defined space where community members through their collective actions can preserve the integrity of the environment and thus the sustainability of their livelihoods and way of life. More generally, the idea of the global commons relates to the notion of cultural and natural resources accessible to all members of a society, including natural materials such as air, water, and a habitable earth. A study by sociologists Laval and Dardot (2015) defines the 'commons' (el común) in similar terms as a social space where participants or inhabitants through their collective actions and autonomy can preserve the environment and the integrity of the community from the 
depredations of capitalism and construct their own alternative future in a sustainable fashion. This conception of 'the commons' resembles that of Bollier and colleagues (BOLLIER, 2014; BOLLIER \& SILKE, 2012; CAFFENTZIS \& FEDERICI, 2013), who describe the 'commons' as a 'template for transformation', a 'world beyond market and state' (i.e. capitalism). In this paper, however, 'the commons' is understood and used in the way that Marx did, as an economic and social space where communities of producers and workers could access the resources needed for subsistence and to sustain their diverse economic activities. The 'enclosure of the commons' in this sense implies denying access of the community to the land, water and other resources needed for the subsistence of community members, including forest resources and wildlife-and in the contemporary context of extractive capitalism—subsoil resources such as minerals and metals, access to which can be conceded to multinational corporations for the purpose of exploration and extraction.

3 The problem with this notion of 'communities in struggle' - and it is a fundamental problem-is the notion of 'community', namely the implicit (or sometimes explicit) assumption that people in a defined geographic space share not only a territory or locality but a culture of solidarity that allows them to collect collectively in the common interest. As argued by O'Malley (2001) among others-even promoters of a strategy of local development (for example, DURSTON, 1998) - this notion more often than not flies in the face of reality. In many cases communities so defined, or idealized (as sharing not only a geographic space but a culture of solidarity) do not actually exist; in actuality many of these so-called 'communities are class divided and unable to collect collectively. To constitute these communities as 'political actors' or collective agents - as so many scholars in the postmodernist camp do - is a rather romantic and idealised notion with rather limited or dubious utility in social scientific analysis.

4 On the dynamics of this struggle, and an analysis of development as imperialism (a soft power strategy to ensure the advance of capital and to obviate the need to resort to a hard power of military force) see Veltmeyer (2005).

5 On the policy dynamics of these'structural reforms' see, inter alia, Petras \& Veltmeyer (2001).

6 Saxe-Fernandez and Nuñez (2001) calculated that the expanded inflows of capital over the decade functioned as a species of syphon, to transfer to the 'centre' of the system up to 100 billion USD, a massive pool of capital that was undoubtedly used to advance the process of capitalist development in the centre of the system.

7 On the formation of this semiproletariat - which provided capital (in the words of the economist Arthur Lewis) with 'unlimited supply of surplus labour' — see Delgado Wise \& Veltmeyer (2016).

8 Since its inception in 1984 the MST has led more than 2,500 land occupations, settling about 370,000 families on 7.5 million hectares of land won as a result of the occupations. Through their organizing drives the MST has created and continued to push for schools, credit for agricultural production and cooperatives, and access to healthcare. Currently, there are approximately 900 encampments holding 150,000 
landless families. Those camped (assentados), as well as those already settled, remain mobilized, ready to join the class struggle and fight for the realization of their political, social economic, environmental and cultural rights.

9 Development can be understood in two ways, first in structural terms as a process (as in capitalist 'development of the forces of production), and secondly in strategic terms as a'project' - actions taken and programs designed in function of a strategy.

10 Vargas represented the indigenous nationalities in the Amazonian region of Ecuador, which had been thoroughly penetrated by the evangelical churches, and because their interests were tied more to territorial autonomy and ethnic cultural identity than the land, it was not too difficult for World Bank officials to 'turn' him away from the confrontational politics of the class and land struggle towards their ethnodevelopment strategy and local micro-project development approach to'change'. Vargas now heads PRODEPINE, an NGO that is well-financed by the World Bank with a large staff that operates in the localities and communities of the rural indigenous poor so as to build on the social capital of the poor rather than mobilize the forces of resistance.

11 There is another modality of social change, which is to eschew electoral politics and bring together social mobilization and local development from below. This idea echoes the view advanced by Bollier (2014), Caffentzis and Federici (2013), and will be briefly discussed below.

12 On the policy and political dynamics of this progressive cycle see Katz (2016), Gaudichaud (2012) and Petras \& Veltmeyer (2017).

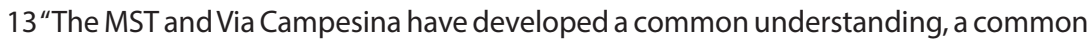
reading, of the historical evolution of capitalism in Brazil. We had four centuries of what might be called the'agro-export model', which was inaugurated by colonial capitalism. Industrial capitalism was not really implanted until 1930 [as] a model of dependent industrialization, because it was so highly dependent on foreign capital"(STEDILE, 2008).

14 Marini (1974) was one of the few exponents of 'dependency theory' who explained the dynamics of uneven capitalist development in terms of a Marxist theory of labour exploitation. He argued that development in the centre of the world system was based on 'super-exploitation', i.e. remunerating the labour of workers and producers in peripheral social formations not at its value (exploitation) but below its value (superexploitation). He also elaborated a theory of class struggle and the resistance to the superexploitation of workers and peasants in the form and with the agency of revolutionary social movements.

15 Landgrabbing makes reference to what the Food and Agriculture Organization of the United Nations (FAO) terms 'large-scale investments in the acquisition of land'. This phenomenon has expanded dramatically both in Latin America and elsewhere in the context of what might be described as 'agro-extractivism'.

16 Post-development, as Gudynas understands it-i.e. with reference to the indigenous concept of Vivir Bien (Bolivia) or Buen vivir (Ecuador): to live in social solidarity and harmony with nature - is anti-systemic (constructed within a'non-capitalist paradigm') but as opposed to socialism and any form of'structuralism' as it is to capitalism. 
17 The opposition of the most 'progressive' postneoliberal regimes in the region, namely Bolivia and Ecuador, to the forces of resistance on the extractive frontier is a function of the regimes' dependence on extractive capital, a dependence that has led these regimes to side with capital (the multinational corporations in the extractive sector) in their relation of conflict with the communities that are negatively impacted by their extractive operations. On this see Veltmeyer \& Petras (2014)

\section{REFERENCES}

ABYA YALA. Diálogo de Alternativas y Alianzas de los Movimientos Indígenas, Campesinos y Sociales del Abya Yala. Minga Informativa de Movimientos Sociales, n.26, La Paz, 2009.

ACOSTA, A. La maldición de la abundancia. Quito: Comité Ecuménico de Proyectos CEP, Ediciones Abya-Yala, 2009.

. Extractivismo y neoextractivismo: dos caras de la misma maldición. In: LANG, M.; MOKRAMI, D. (Ed.) Mas allá del Desarrollo. Quito: Abya Yala, 2011.

AUTY, R. M. Sustaining Development in Mineral Economies: The Resource Curse Thesis. London: Routledge, 1993.

BARRETT, P.; CHAVEZ, D.; RODRÍGUEZ-GARAVITO, C. (Ed.). The New Latin American Left: Utopia Reborn. London: Pluto Press, 2008.

BEBBINGTON, A. The New Extraction: Rewriting the Political Ecology of the Andes? NACLA Report on the Americas, 42(5), p. 12-21, 2009.

BURY (Ed.). Subterranean Struggles: New dynamics of mining, oil and gas in Latin America. Austin: University of Texas Press, 2013.

HICKEY, S.; MITLIN, D. C. (Ed.). Can NGOs Make a Difference: The Challenge of Development Alternatives. London: Zed Books, 2008.

BOLLIER, D. The Commons as a Template for Transformation. Great Transformation Initiative, April, 2014. Disponível em: <http://www.greattransition.org/publication/ the-commons-as-a-template-for-transformation $>$.

. HELFRICH, S. The Wealth of the Commons: A World Beyond Market and State. Amherst, MA: Levelers Press, 2012.

BORRAS Jr., S.M.; FRANCO, J.C.; GÓMEZ, S.; KAY, C.; SPOOR, M. Land Grabbing in Latin America and the Caribbean. Journal of Peasant Studies, vol. 39, n. 3-4, p. 845-872, may 2012.

BURBACH, R. Roots of the Postmodern Rebellion in Chiapas. New Left Review, vol.1, n. 205, may-june, 1994.

CAFFENTZIZ, G.; FEDERICI, S. Commons Against and Beyond Capitalism. Upping the Anti: a journal of theory and action. N. 15, p. 83-97, set. 2013 and Community Development Journal, Special Supplement, vol. 49, Supplement 1, p. 92-105, jan. 2014. 
COLLIER, P.;VENABLES, A. J. Plundered Nations? Successes and Failures in Natural Resource Extraction. London: Palgrave Macmillan, 2011.

CYPHER, J. Neoextraccionismo y Primarización: ¿La subida y decadencia de los términos del intercambio en América del Sur? International Seminar Como Sembrar el Desarrollo en América Latina, UNAM-IIE. México, DF, out. 29-31, 2012.

DURSTON, J. Building Social Capital in Rural Communities (Where it Doesn't Exist): Theoretical and Policy Implications of Peasant Empowerment in Chiquimula. Guatemala, Santiago: ECLAC, 1998.

ECHALAR FLORES, Humberto. El Estado ficticio al Estado real (Plurinacional). Cochabamba: Editorial Kipus, 2015.

FIDH - Federación Internacional de Derechos Humanos (2015). Criminalización de la protesta social frente a proyectos extractivos en Ecuador. 2015. Disponível em: <www. fidh.org>.

FINE, B.; JOMO, K. S. (Ed.). The New Development Economics: After the Washington Consensus. London: Zed Books, 2006.

FPIMCCBV - Foro de los Pueblos indígenas, minería, cambio climático y buen vivir. Suscribe Declaración. Lima: Servicios en Comunicación Intercultural Servindi, n. 23, nov. 2010.

GAUDICHAUD, F. El volcán latinoamericano. Izquierdas, movimientos sociales y neoliberalismo en América Latina. Otramérica. 2012. Disponível em: <http://blogs. otramerica.com/editorial/>.

GIRVAN, N. Extractive Imperialism in Historical Perspective, p. 49-61. In: PETRAS, J.; VELTMEYER, H. (Ed.). Extractive Imperialism in the Americas. Leiden: Brill Books, 2014.

GRUGEL, J.; Riggirozzi, P. Post Neoliberalism: Rebuilding and Reclaiming the State in Latin America. Development and Change, vol. 43, n. 1, 2012.

GUDYNAS, E. Diez tesis urgentes sobre el nuevo extractivismo. Contextos y demandas bajo el progresismo sudamericano actual. In: Extractivismo, Política y Sociedad. Quito: CLAES/CAAP, p. 187-225, 2009. Disponível em: <http://extractivismo.com/documentos/capitulos/GudynasExtractivismoSociedadDesarrollo09.pdf>.

. Postextractivismo y alternativas al desarrollo desde la sociedad civil. In: Alternativas al capitalismo. Colonialismo del Siglo XXI. Quito: Ediciones Abya Yala, p.189-224, 2013.

HARVEY, D. The New Imperialism. Oxford: Oxford University Press, 2003.

HOLLOWAY, J. Change the Word Without Taking Power: The Meaning of Revolution Today. London: Pluto Press, 2002.

INFANTE, R. B.; SUNKEL, O. Chile: Hacia un desarrollo inclusive. Revista CEPAL, vol. 10, n. 97, p. 135-154, 2009. 
IWGIA - International Work Group for Indigenous Affairs. The Indigenous World 2010. Copenhagen. 2010.Disponível em:<http://www.iwgia.org/iwgia_files_publications_files/0001_I_2010_EB.pdf>.

KATZ, C. Is South America's 'Progressive Cycle' At an End? Neo-Developmentalist Attempts and Socialist Projects. The Bullet, E-Bulletin, n.1229, mar. 4, 2016.

LAVAL, C.; DARDOT, P. Común: Ensayo sobre la revolución en el siglo XXI. Barcelona: Gedisa Editorial, 2015.

LEVITSKY, S.; ROBERTS, K. (Ed.) The Resurgence of the Latin American Left. Baltimore: Johns Hopkins University Press, 2011.

MACDONALD, L.; RUCKERT, A. Post-Neoliberalism in the Americas. Basingstoke. UK: Palgrave Macmillan, 2009.

MARINI, R. M. Subdesarrollo y revolución. México: Siglo XXI Editores, 5th edn, 1974.

Dialéctica de la dependencia. Buenos Aires e Bogotá: CLACSO/ Siglo del Hombre Editores. 2008 [1973]. Disponível em: <http://bibliotecavirtual.clacso.org.ar/ clacso/se /20100830091927/04dialectica2.pdf>.

MARTINEZ-ALIER, J. The Environmentalism of the Poor: A Study of Ecological Conflicts and Valuation. London: Edward Elgar Publishing, 2003.

MITLIN, D. The NGO Sector and its Role in Strengthening Civil Society and Securing Good Governance. In: BERNARD, A.; HELMICH, H.; LEHNING, P. (Ed.), Civil Society and International Development. Paris: OECD Development Centre, 1998.

OCMAL_Observatorio de Conflictos Mineros de América Latina (2011). Mapa de conflictos mineros, proyectos y empresas mineras en América Latina. 2011. Disponível em: <http://mapa.conflictosmineros.net/ocmal_db>.

O'MALLEY, A. Community vs. Class. In:VELTMEYER, H.; O'MALLEY, A. (Ed.). Transcending Neoliberalism: Community-Based Development in Latin America. West Hartford Conn: Kumarian Press, 2001.

PETRAS, J; VELTMEYER, H. Globalization Unmasked: Imperialism in the 21st Century. London: ZED Press / Halifax: Fernwood Publishing, 2001.

. Las privatizaciónes y la desnacionalización en América Latina. Buenos Aires: Libros Prometeo, 2004.

. Movimientos sociales y poder estatal. Buenos Aires: Editorial Lumen, 2005.

. Social Movements and the State: Political Power Dynamics in Latin America, Critical Sociology, v. 32, n.1, 2006.

Espejismos de la Izquierda en América Latina. Buenos Aires: Editorial Lumen, 2009.

. The Class Struggle in Latin America: Contemporary Dynamics. London: Routledge, 2017. 
PETRAS, J.; ZEITLIN, M. Latin America: Reform or Revolution? A Reader, 1968.

POLISCHUK, S. Massacres of the extractivist industry: poisoning and criminalisation of our towns and indigenous peoples. The Dawn, jan. 5, 2016. Disponível em: <http:// www.thedawn-news.org/2016/01/05/massacres-of-the-extractivist-industry-poisoning-and-criminalisation-of-our-towns-and-indigenous-peoples $>$.

PRADA ALCOREZA, R. Miseria de la geopolítica: Crítica a la geopolítica extractivista. America Latina en Movimiento, out. 18, 2012. Disponível em: <http:// www.alainet. org/es/active/58901>.

Buen Vivir as a Model for State and Economy. In: LANG, M.; MOKRANI, D. Beyond Development: Alternative Visions from Latin America. Amsterdam:Transnational Institute, p. 145-158, 2013.

ROBLES, W.; VELTMEYER, H. The Politics of Agrarian Reform in Brazil: The Landless Rural Workers Movement. Basingstoke, UK. New York: Palgrave Macmillan, 2015.

SAGUIER, M. Minería para el desarrollo integral en la estrategia de UASUR. Presentation to the Conference ISA/FLACSO. Buenos Aires, July 23-2, 2014.

SAXE-FERNÁNDEZ, J.; NUÑEZ, O. Globalización e Imperialismo: La Transferencia de Excedentes de América Latina. In: SAXE-FERNÁNDEZ, J. et al. Globalización, Imperialismo y Clase Social. Buenos Aires/México: Editorial Lumen, 2001.

SCHUURMANN, F. Beyond the Impasse: New Directions in Development Theory. London: Zed Books., 1993.

SENA-FOBOMADE. Se intensifica el extractivismo minero en América Latina. Foro Boliviano sobre Medio Ambiente y Desarrollo, 03-02, 2011. Disponível em: <http:// fobomade.org.bo/art-1109>.

SPRONK, S.; WEBBER, J. R. Struggles against Accumulation by Dispossession in Bolivia: The Political Economy of Natural Resource Contention. Latin American Perspectives, vol. 34, n. 2, p.31-47, mar. 2007.

STEDILE, J. P. The Class Struggles in Brazil:The Perspective of the MST. Socialist Register, vol. 44, p.193-216, 2008.

TETREAULT, D. Mexico: The Political Ecology of Mining. In: VELTMEYER, H.; PETRAS, J. (Ed.). The New Extractivism. London: Zed Books, P. 172-191, 2014.

VELTMEYER, H. Development and Globalization as Imperialism. Canadian Journal of Development Studies, XXVI, n.1, p. 89-106, 2005.

. PETRAS, J. The New Extractivism. London: Zed Books, 2014.

. New Social Movements in Latin America: the Dynamics of Class and Identity. The Journal of Peasant Studies, vol. 25, n.1, oct. 1997.

VIA CAMPESINA. Agrarian Reform in the 21st Century: Building a New Vision. Redefining Strategies, and Celebrating Victories. Press Release, jul. 19, 2012. 
VIA CAMPESINA-BRAZIL. Por qué nos movilizamos?. ALAI-América Latina en Movimiento, Asemblea Popular, jun. 10, 2008. Disponível em: <http://alainet.org/active/24605\& langes $>$.

WEBBER, J. Left-Indigenous Struggles in Bolivia: Searching for Revolutionary Democracy. Monthly Review, 57(4), set. 2005.

. Evismo: Reform? Revolution? Counter-Revolution? International Viewpoint. IV382 - out, 2006. Disponível em: http://www.internationalviewpoint. org

WISE, R. D.; VELTMEYER, H. Agrarian Transformation, Migration and Development. Canada: Halifax Fernwood Publications, 2016.

WORLD BANK. World Development Report 2008: Agriculture for Development. New York: Oxford University Press, 2008.

ZIBECHI, R. La nueva geopolítica del capital. AL Al, América Latina en Movimiento. Le Monde Diplomatique Colombia, abr. 19, 2012a. Disponível em: <http://www.alainet. org/es/active/54196>.

. Territories in Resistance: A Cartography of Latin American Social Movements.

Oakland, CA: AK Press, 2012b.

Henry Veltmeyer: Professor of Sociology and International Development Studies at St. Mary's University (Halifax, Canada) and Development Studies at the Universidad Autónoma de Zacatecas, in Mexico. $\mathrm{He}$ is author, coauthor and editor of over 40 books on Latin American social movements and issues of Latin American and world development, including Dynamics of Social Change in Latin America (2007); and, with James Petras,; Multinationals on Trial (2007); and What's Left in Latin America (2009).

E-mail: hveltmeyer@smu.ca. 